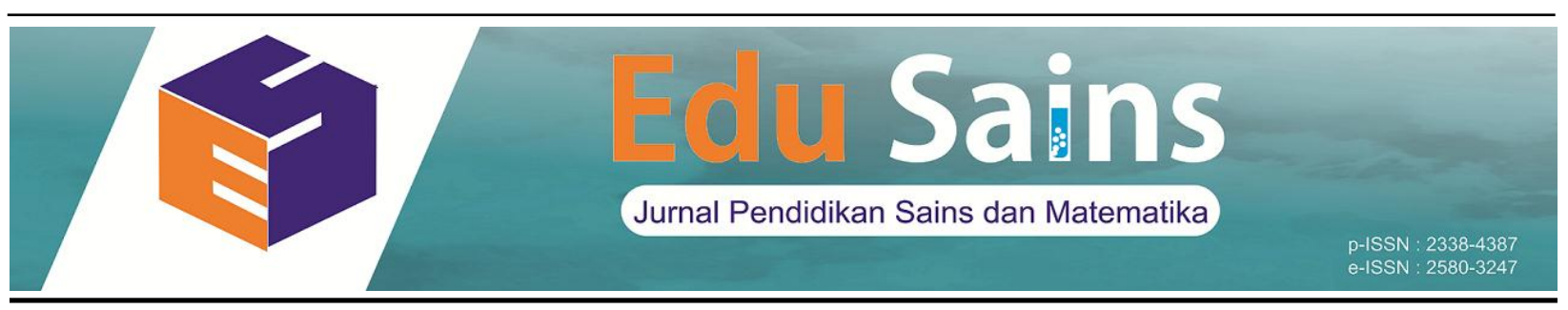

\title{
PENERAPAN MODEL PROBLEM BASED LEARNING UNTUK MENINGKATKAN KETERAMPILAN BERPIKIR KRITIS PESERA DIDIK
}

\author{
Catur Okti Windaria, Fitri April Yanti ${ }^{b *}$ \\ Email:april.ynwa@gmail.com \\ aPendidikan Fisika, SMA Miftahul Ulum Seputih Surabaya, Lampung, Indonesia \\ ${ }^{b *}$ Pendidikan Sains, Universitas Bengkulu, Bengkulu, Indonesia
}

\begin{abstract}
Abstrak
Penelitian ini bertujuan untuk meningkatkan kemampuan berpikir kritis pesera didik kelas XI SMA Negeri 1 Sekampung dalam pembelajaran fisika melalui model pembelajaran berbasis masalah. Penelitian ini menggunakan jenis penelitian tindakan kelas, dimana peneliti mengamati secara langsung objek di lapangan yang meliputi dua siklus pembelajaran, satu siklus meliputi perencanaan, pelaksanaan, observasi dan refleksi. Sebagai objek dalam penelitian ini adalah 30 pesera didik kelas XI IPA 3 SMA Negeri 1 Sekampung. Metode pengumpulan data keterampilan berpikir kritis menggunakan tes uraian, sedangkan data kegiatan pembelajaran berbasis masalah menggunakan lembar observasi. Hasil penelitian ini adalah mengintegrasikan langkah-langkah pembelajaran berbasis masalah ke dalam keterampilan berpikir kritis, sehingga dapat meningkatkan keterampilan berpikir kritis pesera didik pada keterampilan analisis sebesar $64,44 \%$ pada siklus I dan 75, 55\% pada siklus II, keterampilan berpikir sintesis 57, 77\% pada siklus I dan $66,66 \%$ pada siklus II, keterampilan berpikir pemecahan masalah $38,88 \%$ pada siklus I dan $72,22 \%$ pada siklus II, keterampilan menyimpulkan 52, 22\% pada siklus I dan $70 \%$ pada siklus II, dan keterampilan mengevaluasi atau menilai $47,77 \%$ pada siklus I dan $62,22 \%$ pada siklus II pada pesera didik kelas XI SMA Negeri 1 Sekampung pada materi statik fluida Tahun Ajaran 2015/2016.
\end{abstract}

Kata Kunci: keterampilan berpikir kritis, pembelajaran fisika, problem based learning

\begin{abstract}
This research aims to improve the critical thinking skills of eleventh (XI) graders of SMA Negeri 1 Sekampung in physics subject through problem-based learning model. The research design used was classroom action research with thirty (30) XI graders of Science study program as the subject and observed directly within two learning cycles in which each cycle consisted of planning, implementation, observation and reflection. The data were collected by means of tests and observation checklist. The results of this study indicated that problem-based learning model were improving students' critical thinking skills of analysis by $64.44 \%$ in cycle I and $75.55 \%$ in cycle II, thinking skills of sintesis by $57.77 \%$ in cycle I and $66.66 \%$ in cycle II, problem solving skills of $38.88 \%$ in cycle I and $72.22 \%$ in cycle II, concluding skills of $52.22 \%$ in cycle I and $70 \%$ in cycle II, and the skills of evaluating or assessing $47.77 \%$ in cycle I and $62.22 \%$ in cycle II with static fluids learning material for eleventh (XI) graders of SMA Negeri 1 Sekampung in academic year 2015/2016.
\end{abstract}

Keywords: critical thinking skills, physics learning, problem based learning 


\section{PENDAHULUAN}

Pendidikan merupakan salah satu faktor penting dalam kemajuan suatu negara. Di bidang pendidikan merupakan proses pembinaan dan pengembangan sumber daya manusia yang secara langsung bermanfaat bagi mencerdaskan kehidupan bangsa. Pengembangan sumberdaya manusia dapat dicapai melalui perkembangan sains. Pembelajaran fisika merupakan salah satu pembelajaran yang menunjang perkembangan sains, bukan hanya kumpulan ilmu yang berupa teori dan fakta, melainkan berupa penemuan-penemuan. Pembelajaran fisika menggunakan pendekatan empiris untuk mencari penjelasan alamiah atas fenomena yang diamati di alam semesta. Hal tersebut sesuai dengan Jufri (2013: 4) "penelitian empiris pada umumnya dilakukan dengan menggunakan metode ilmiah sebagai proses kerja". Selain itu juga, pembelajaran fisika melalui pendekatan ilmiah melatih munculnya keterampilan berpikir (Ansori et al., 2017; Hanna et al., 2016; Pratama \& Istiyono, 2015; Suprapto et al., 2013). Pembelajaran fisika dalam implementasinya di kelas, memerlukan model pembelajaran yang tepat untuk pesera didik.

Pemilihan model pembelajaran memerlukan pertimbangan kesesuaian kondisi pesera didik dengan materi yang akan diajarkan. Berdasarkan wawancara dengan guru mata pelajaran fisika, metode yang digunakan guru adalah metode eksperimen. Pesera didik telah terbiasa melakukan eksperimen dalam pembelajaran fisika. Metode ekseperimen memberikan keterampilan memecahkan masalah, menyimpulkan, mengevaluasi atau menilai. Keterampilan memecahkan masalah, menyimpulkan, evaluasi atau menilai, menjadi bagian dari aspek keterampilan berpikir kritis (Pursitasari et al., 2020). Hal ini berarti, melalui kegiatan eksperimen, pesera didik hanya melakukan sebanyak tiga dari lima keterampilan berpikir kritis. Oleh karena itu diperlukan model pembelajaran untuk memaksimalkan keterampilan berpikir kritis pesera didik, salah satunya adalah model pembelajaran berbasis masalah.

Berdasarkan hasil survei yang dilakukan di SMA Negeri 1 Sekampung diketahui bahwa nilai keterampilan berpikir kritis pesera didik yang meliputi keterampilan analisis, sintesis, memecahkan masalah, menyimpulkan, dan evaluasi atau menilai masih kurang optimal. Hal ini ditunjukkan pada Tabel 1 berikut:

Tabel 1. Nilai rata-rata pencapaian skor keterampilan berpikir kritis pesera didik SMA Negeri 1 Sekampung

\begin{tabular}{lc}
\hline \multicolumn{1}{c}{ Aspek keterampilan berpikir kritis } & $\begin{array}{c}\text { Persentase Nilai rata-rata } \\
\text { pencapaian skor }\end{array}$ \\
\hline Keterampilan berpikir analisis & $20 \%$ \\
Keterampilan berpikir sintesis & $30 \%$ \\
Keterampilan berpikir memecahkan masalah & $20 \%$ \\
Keterampilan menyimpulkan & $40 \%$ \\
Keterampilan mengevaluasi atau menilai & $30 \%$ \\
\hline
\end{tabular}

(Sumber: dokumen penulis) 
Tabel 1 menunjukkan pada keterampilan analisis, jawaban yang diberikan pesera didik kurang sesuai dengan apa yang dimaksud dalam soal, berisi informasi yang tidak akurat, atau menunjukkan kurangnya penggunaan terhadap materi. Keterampilan sintesis, keterkaitan antara jawaban dengan soal kurang jelas. Keterampilan memecahkan masalah, hubungan antara jawaban dengan soal belum tergambar secara jelas. Keterampilan menyimpulkan, poin-poin jawaban yang diberikan pesera didik belum jelas, dan keterampilan evaluasi atau menilai, jawaban pesera didik belum memberikan contoh yang mendukung dengan jelas. Berdasarkan survei tersebut, maka diperlukan model pembelajaran yang dapat meningkatkan keterampilan berpikir kritis pesera didik.

Model pembelajaran berbasis masalah memiliki tahapan pembelajaran masalah dimana terdapat kegiatan observasi langsung yang dapat menimbulkan pemikiran kritis pesera didik. Pembelajaran berbasis masalah memberikan kontribusi kepada pesera didik dalam berpikir tingkat tinggi atau berpikir kritis (Masek \& Yamin: 2011; Amin et al., 2020; Lisniandila et al., 2019; Liyuan \& Group, 2017; Rubiyanti et al., 2020). Selain itu juga, guru menjadi fasilitator dalam model problem based learning (Emiliasari et al., 2019). Model pembelajaran berbasis masalah memiliki langkah pembelajaran masalah yang di dalamnya terdapat kegiatan eksperimen. Pesera didik di kelas XI IPA 1 SMA Negeri 1 Sekampung, sudah terbiasa melakukan eksperimen maka model pembelajaran berbasis masalah ini dapat diterapkan didalam proses pembelajaran di kelas XI IPA 1. Pembelajaran berbasis masalah menyediakan kondisi untuk meningkatkan keterampilan berpikir kritis dan analitis serta memecahkan masalah kompleks dalam kehidupan nyata sehingga akan memunculkan budaya berpikir pada diri pesera didik. Langkah problem based learning yang digunakan meliputi: 1) penyajian masalah, 2) mengorganisasi pesera didik untuk belajar, 3) membantu investigasi mandiri dan kelompok dengan menggunakan langkah-langkah pemecahan masalah Polya, yaitu a) memahami masalah, b) menyusun rencana, c) melaksanakan rencana, dan d) mengecek kembali, 4) mengembangkan dan mempresentasikan hasil karya, dan 5) menganalisis dan mengevaluasi proses pemecahan masalah (Sam \& Qohar, 2016).

Berdasarkan latar belakang tersebut, penelitian ini mengambil judul "Penerapan Model Pembelajaran Berbasis Masalah untuk Meningkatkan Keterampilan Berpikir Kritis Pesera didik Kelas XI SMA Negeri 1 Sekampung Tahun Ajaran 2015/2016".

\section{METODE}

Penelitian ini menggunakan penelitian tindakan kelas (PTK), dimana peneliti mengamati secara langsung objek-objek di lapangan yang meliputi dua siklus pembelajaran, satu siklus meliputi perencanaan, pelaksanaan, observasi dan refleksi. Siklus PTK terdapat pada Gambar 1. 


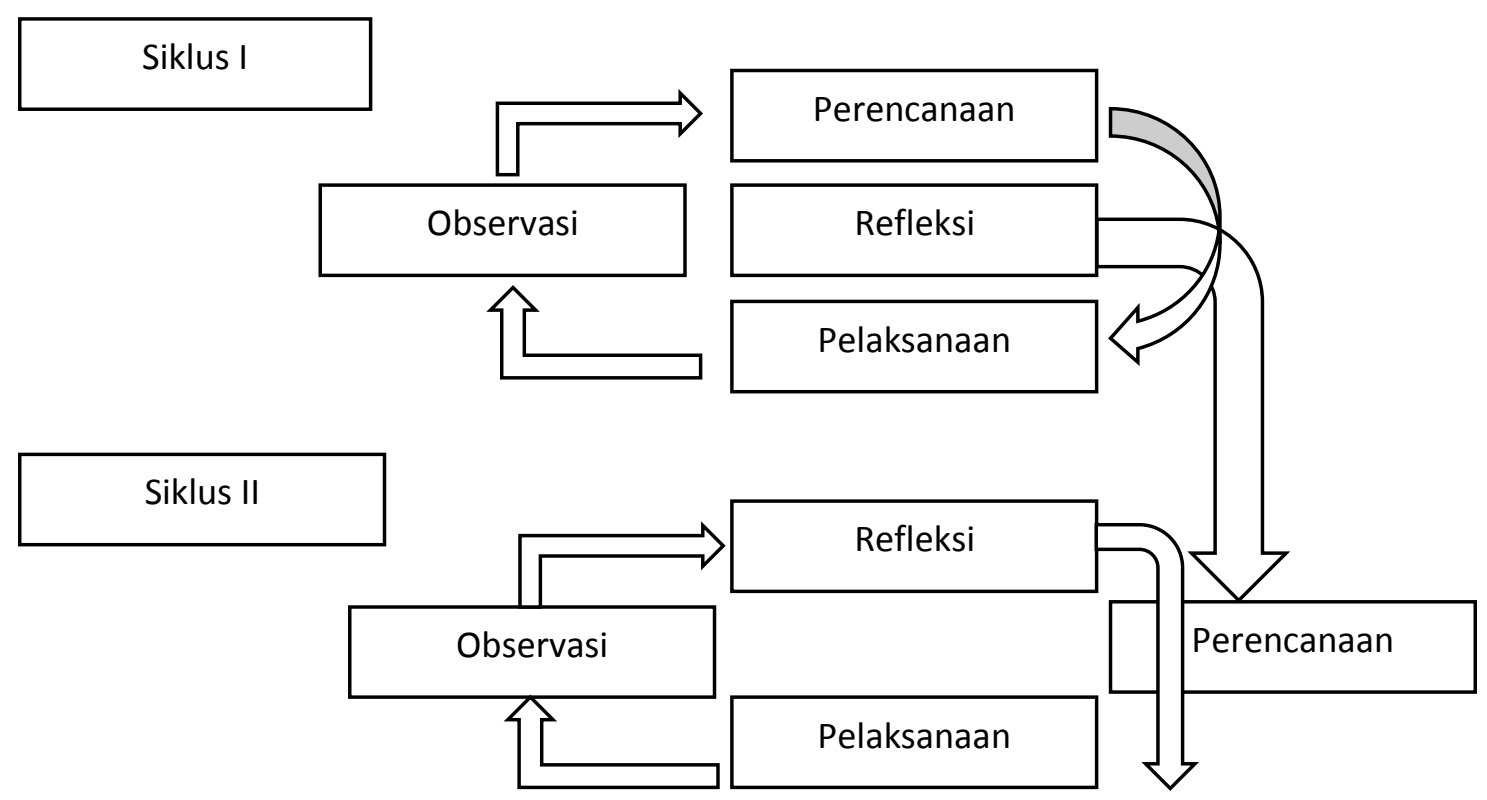

Gambar 1. Siklus PTK

Sebagai objek penelitian ini adalah 30 pesera didik kelas XI IPA 3 SMA Negeri 1 Sekampung. Metode pengumpulan data keterampilan berpikir kritis menggunakan tes uraian, sedangkan data kegiatan pembelajaran berbasis masalah menggunakan lembar observasi. Ujian keterampilan berpikir kritis dilaksanakan di akhir pertemuan pada setiap siklus dengan materi 5 soal tekanan hidrostatis dan hukum Archimedes. Data proses pembelajaran berbasis masalah diambil selama proses pembelajaran dengan menggunakan model pembelajaran berbasis masalah dengan dibantu oleh tiga orang pengamat. Untuk memperoleh hasil pengukuran data yang valid dan reliabel, terlebih dahulu dilakukan uji ahli untuk mengetahui tingkat validitas dan reliabilitas alat ukur.

\section{HASIL DAN PEMBAHASAN}

\section{Proses Pembelajaran Berbasis Masalah}

Hasil analisis data menunjukkan nilai proses pembelajaran meningkat dari siklus I ke siklus II. Peningkatan proses pembelajaran dapat dilihat pada Tabel 2.

Tabel 2. Data Proses Pembelajaran Berbasis Masalah pada Siklus I dan Siklus II

\begin{tabular}{|c|c|c|c|c|c|c|c|c|}
\hline \multirow{3}{*}{$\begin{array}{c}\begin{array}{c}\text { Per } \\
\text { temuan }\end{array} \\
1\end{array}$} & \multicolumn{3}{|c|}{$\begin{array}{l}\text { Skor yang diberikan observer } \\
\text { pada proses pembelajaran } \\
\text { berbasis masalah Siklus I }\end{array}$} & \multirow[t]{3}{*}{ Ket } & \multicolumn{3}{|c|}{$\begin{array}{l}\text { Skor yang diberikan observer } \\
\text { pada proses pembelajaran } \\
\text { berbasis masalah Siklus II }\end{array}$} & \multirow[t]{2}{*}{ Ket } \\
\hline & Observer & Observer & Observer & & Observer & Observer & Observer & \\
\hline & 1 & 2 & 3 & & 1 & 2 & 3 & \\
\hline & 31 & 33 & 32 & Baik & 43 & 39 & 42 & Baik \\
\hline 2 & 33 & 34 & 35 & Baik & 44 & 41 & 44 & Baik \\
\hline
\end{tabular}

Pada Tabel 2, diketahui bahwa skor pada siklus I dan siklus II mengalami peningkatan, hal ini berarti proses pembelajaran menggunakan model pembelajaran berbasis masalah semakin meningkat. 


\section{Keterampilan Berpikir Kritis}

Hasil analisis data menunjukkan nilai keterampilan berpikir kritis meningkat dari siklus I ke siklus II. Peningkatan proses pembelajaran dapat dilihat pada Tabel 3.

Tabel 3. Data Skor Keterampilan Berpikir Kritis pesera didik dari Pra PTK, siklus I sampai dengan siklus II

\begin{tabular}{|c|c|c|c|c|c|c|}
\hline \multirow[b]{2}{*}{ No } & \multirow{2}{*}{$\begin{array}{l}\text { Aspek Keterampilan Berpikir } \\
\text { Kritis }\end{array}$} & \multicolumn{3}{|c|}{ Persentase } & \multirow[b]{2}{*}{ Target } & \multirow{2}{*}{$\begin{array}{l}\text { Ket. } \\
\text { target }\end{array}$} \\
\hline & & Pra PTK & Siklus I & $\begin{array}{c}\text { Siklus } \\
\text { II }\end{array}$ & & \\
\hline 1 & Keterampilan berpikir analisis & 20,37 & 64,44 & 75,55 & 40 & Tercapai \\
\hline 2 & Keterampilan berpikir sintesis & 29,62 & 57,77 & 66,66 & 50 & Tercapai \\
\hline 3 & $\begin{array}{l}\text { Keterampilan berpikir } \\
\text { memecahkan masalah }\end{array}$ & 20,37 & 38,88 & 72,22 & 40 & Tercapai \\
\hline 4 & Keterampilan menyimpulkan & 39,81 & 52,22 & 70 & 60 & Tercapai \\
\hline 5 & $\begin{array}{l}\text { Keterampilan mengevaluasi } \\
\text { atau menilai }\end{array}$ & 29,62 & 47,77 & 62,22 & 50 & Tercapai \\
\hline
\end{tabular}

Berdasarkan Tabel 3 dapat dilihat bahwa tiap aspek keterampilan berpikir kritis dalam penelitian mengalami peningkatan dengan menggunakan model pembelajaran berbasis masalah. Keterampilan berpikir kritis telah mencapai persentase target skor pesera didik yang diinginkan sebagai indikator keberhasilan tindakan.

Persentase skor keterampilan berpikir kritis pesera didik pada siklus I belum seluruhnya mencapai target keberhasilan penelitian. Keterampilan berpikir kritis perlu dimunculkan berdasarkan rancangan pembelajaran yang tepat (Basri \& As,ari, 2018). Pada siklus II persentase skor keterampilan berpikir kritis pesera didik yang mencapai KKM telah mencapai target keberhasilan. Peningkatan persentase ini disebabkan pembelajaran yang dilakukan dengan menggunakan model pembelajaran berbasis masalah dapat meningkatkan keterampilan berpikir kritis pesera didik. Hal ini sesuai Ibrahim dan Nur (dalam Rusman, 2012: 241) menyatakan bahwa pembelajaran berbasis masalah merupakan salah satu pendekatan pembelajaran yang digunakan untuk merangsang berpikir tingkat tinggi pesera didik dalam situasi yang berorientasi pada masalah dunia nyata, termasuk di dalamnya belajar bagaimana belajar. Adapun permasing-masing ketercapaian indikator adalah sebagai berikut.

\section{a. Keterampilan berpikir analisis}

Keterampilan berpikir analisis yang dimaksud adalah keterampilan dalam mengidentifikasi masalah. Keterampilan mengidentifikasi masalah ditunjukkan dengan jawaban pesera didik yang mempu memberikan jawaban dengan alasan yang logis dan sesuai dengan fakta yang di ungkapkan. Hal ini terlihat pada jawaban pesera didik yang memberikan konsep yang tepat dalam pertanyaan yang ada. Keterampilan berpikir kritis berhubungan dengan gaya berpikir pesera didik mulai dari konkret hingga abstrak (Firdaus et al., 2019). 
Tabel 3 dapat diketahui pada siklus I, persentase skor keterampilan berpikir analisis adalah sebesar $64,44 \%$. Dari hasil skor pesera didik mengobservasi pada siklus I, data menunjukkan bahwa skor pesera didik pada keterampilan berpikir analisis sudah mencapai target yaitu 60\%. Pada persentase ini pesera didik ditunjukkan dengan jawaban pesera didik yang mampu memberikan jawaban dengan alasan yang logis dan sesuai dengan fakta yang di ungkapkan, tetapi kurang lengkap dalam penjabarannya. Pada siklus II persentase skor keterampilan berpikir analisis sebesar $75,55 \%$, pada persentase ini jawaban yang diberikan pesera didik alasan yang logis dan sesuai dengan fakta yang di ungkapkan, serta jawaban yang diberikan menyeluruh atau mencakup keseluruhan. Kemampuan analisis bukan hanya menyelesaikan perhitungan fisika tetapi mampu memaknai jawabannya (evaluasi) (Priyadi et al., 2018; Purwati et al., 2007).

b. Keterampilan berpikir sintesis

Keterampilan berpikir sintesis yang dimaksud adalah memadukan semua informasi yang diperoleh dari materi bacaan, sehingga dapat memunculkan ide baru. Keterampilan berpikir sintesis pesera didik ditunjukkan dengan pesera didik dalam menjawab pertanyaan sudah secara berurutan hanya jawaban akhir pesera didik kurang tepat. Tabel 3 diketahui bahwa setelah penerapan model pembelajaran berbasis masalah pada pembelajaran siklus I, persentase skor keterampilan berpikir sintesis adalah sebesar $57,77 \%$. Pada persentase ini pesera didik belum mampu secara maksimal menjawab pertayaan. Kondisi tersebut disebabkan jawaban pesera didik masih belum tepat dalam melakukan perhitungan. Pada siklus II setelah dilakukan refleksi pada siklus I maka persentase skor keterampilan berpikir sintesis sebesar $66,66 \%$, pada persentase ini, jawaban pesera didik lengkap dan akurat dalam menjelaskan pengetahuan yang dimilikinya berdasarkan konsep yang ada. Pemaduan informasi yang diperoleh pesera didik melalui berbagai referensi akan menambah pemahaman konsepnya (Prayitno, 2012; Sulaiman \& Syakarofath, 2018).

\section{c. Keterampilan berpikir memecahkan masalah}

Keterampilan berpikir memecahkan masalah yang dimaksud adalah Mengamati peristiwa yang terjadi, dapat berupa menjawab pertanyaan "mengapa?". Hal ini ditunjukkan dengan jawaban pesera didik yang dapat memberikan alasan pada peristiwa yang diungkapkan. Berdasarkan tabel 3, dapat diketahui bahwa setelah penerapan model pembelajaran berbasis masalah pada pembelajaran siklus I, persentase skor keterampilan berpikir memecahkan masalah adalah sebesar $38,88 \%$. Pada persentase ini jawaban pesera didik sudah sistematis tetapi pada akhir penyelesaiannya belum sesuai dengan yang jawaban yang tepat. Pada siklus II persentase skor keterampilan berpikir memecahkan masalah sebesar $72,91 \%$, pada persentase ini jawaban pesera didik sudah mampu menjawab secara berurutan yang meliputi, menuliskan diketahui, ditanya dan dijawab. Kemampuan 
memecahkan masalah dapat dilihat dari kemampuannya menjawab pertanyaan secara runtut (Fuad et al., 2017; Purwati et al., 2007).

\section{d. Keterampilan menyimpulkan}

Keterampilan menyimpulkan yang dimaksud adalah menafsirkan hubungan sebab-akibat. Hal ini terlihat pada jawaban pesera didik yang mampu menguhubungkan dan memprediksi sebab akibat yang akan terjadi. Aspek keterampilan berpikir kritis yaitu menghubungkan dan memprediksi akan muncul melalui kegiatan menyimpulkan (Pursitasari et al., 2020; Suriani et al., 2019). Dari tabel 3, dapat diketahui bahwa setelah penerapan model pembelajaran berbasis masalah pada pembelajaran siklus I, persentase skor keterampilan menyimpulkan adalah sebesar 52,22\%. Pada persentase ini jawaban pesera didik penjabarannya tidak lengkap dan belum menghubungkan sebab akibat. Pada siklus II setelah dilakukan refleksi pada siklus I, persentase skor keterampilan menyimpulkan sebesar $70 \%$. Keterampilan menyimpulkan berkisar pada pengetahuan baru yang dihasilkan (Changwong et al., 2018; Utami et al., 2017).

\section{e. Keterampilan mengevaluasi atau menilai}

Keterampilan mengevaluasi atau menilai yang dimaksud adalah memberi pendapat atas informasi yang telah diperoleh. Berpikir kritis melibatkan logika penalaran yang benar dan kemampuan untuk memisahkan fakta dari opini (Basri \& As,ari, 2018; Yanti et al., 2016). Hal ini terlihat pada jawaban yang diberikan pesera didik disertai dengan pendapat yang baik dan sesuai dengan konsep yang ada. Dari Tabel 3, dapat diketahui bahwa setelah penerapan model pembelajaran berbasis masalah pada pembelajaran siklus I, persentase skor keterampilan mengevaluasi atau menilai adalah sebesar 47,77\%. Pada persentase ini jawaban pesera didik kurang lengkap dan belum mengaitkan konsep. Pada siklus II setelah dilakukan refleksi pada siklus I, persentase skor keterampilan mengevaluasi atau menilai sebesar 62,22\%, pada persentase ini, jawaban pesera didik sudah mengaitkan jawaban dengan konsep yang ada. Hal ini sesuai dengan Surya (2015: 123) menyatakan berpikir kritis merupakan salah satu strategi kognitif dalam pemecahan masalah yang lebih kompleks dan menuntut pola yang lebih tinggi. Kamampuan berpikir kritis secara keseluruhan dapat ditingkatkan melalui model pembelajaran berbasis masalah. Kebiasaan belajar pesera didik yang pasif juga menyebabkan kemampuan berpikir kritis tidak berkembang, pesera didik lebih merasa nyaman dengan penjelasan dari guru tanpa berpartisipasi dalam pembelajaran yang aktif (Dodi et al., 2015; Permata et al., 2019; Priyadi et al., 2018; Siahaan \& Meilani, 2019; Siregar \& Ramadhani, 2019; Susilowati et al., 2017; Sutisnawati, 2017).

\section{SIMPULAN}

Berdasarkan hasil penelitian tindakan kelas yang telah dilakukan dan pembahasan yang telah dikemukakan, maka dapat disimpulkan bahwa dengan 
mengintegrasikan aspek keterampilan berpikir kritis yang meliputi keterampilan berpikir analisis, sintesis, memecahkan masalah, menyimpulkan dan mengevaluasi atau menilai kedalam langkah pembelajaran berbasis masalah, dapat meningkatkan keterampilan berpikir kritis pesera didik kelas XI SMA Negeri 1 Sekampung pada pokok fluida statis Tahun Pelajaran 2015/2016.

Saran kepada guru sebaiknya dapat menentukan kelompok belajar pesera didik secara homogen, sehingga pesera didik dapat berkolaborasi belajar dengan baik dan menggunakan model pembelajaran yang sesuai untuk mengembangkan keterampilan berpikir kritisnya. Saran untuk peneliti lain, hasil penelitian ini dapat digunakan sebagai referensi dalam penelitian di bidang studi lain.

\section{DAFTAR PUSTAKA}

[1] Amin, S., Utaya, S., Bachri, S., Sumarmi, \& Susilo, S. (2020). Effect of problem-based learning on critical thinking skills and environmental attitude. Journal for the Education of Gifted Young Scientists, 8(2), 743-755. https://doi.org/10.17478/jegys.650344

[2] Ansori, Z., Wartono, \& Sutopo. (2017). Pembelajaran multi representasi dengan pendekatan empiris, teoritis dan animasi untuk meningkatkan pemahaman konsep siswa. Seminar Pendidikan IPA Pascasarjana UM, 2, 345-348.

[3] Basri, H., \& As,ari, A. R. (2018). Improving the critical thinking ability of students to solve mathematical task. JIPM (Jurnal Ilmiah Pendidikan Matematika), 7(1), 13. https://doi.org/10.25273/jipm.v7i1.3013

[4] Changwong, K., Sukkamart, A., \& Sisan, B. (2018). Critical thinking skill development: analysis of a new learning management model for thai high schools. Journal of International Studies, 11(2), 37-48. https://doi.org/10.14254/2071-8330.2018/11-2/3

[5] Dodi, Hudiono, B., \& Suratman, D. (2015). Analisis keterampilan berpikir kritis pesera didik pada materi limit fungsi aljabar di kelas $\mathrm{x}$ sma. Jurnal Pendidikan Dan Pembelajaran Khatulistiwa, 4(8), 1-15.

[6] Emiliasari, R. N., Prasetyo, E., \& Syarifah, E. F. (2019). Problem-based learning: developing students' critical thinking. Linguists: Journal of Linguistics and Language Teaching, 5(1), 56. https://doi.org/10.29300/ling.v5i1.1962

[7] Firdaus, A., Nisa, L. C., \& Nadhifah, N. (2019). Kemampuan berpikir kritis pesera didik pada materi barisan dan deret berdasarkan gaya berpikir. Kreano, Jurnal Matematika Kreatif-Inovatif, 10(1), 68-77. https://doi.org/10.15294/kreano.v10i1.17822

[8] Fuad, N. M., Zubaidah, S., Mahanal, S., \& Suarsini, E. (2017). Improving junior high schools' critical thinking skills based on test three different models of learning. International Journal of Instruction, 10(1), 101-116. https://doi.org/10.12973/iji.2017.1017a

[9] Hanna, D., Sutarto, \& Harijanto, A. (2016). Model pembelajaran tema konsep disertai media gambar pada pembelajaran fisika di SMA. Jurnal Pembelajaran Fisika, 5(1), $23-29$.

[10] Jufri, Wahab. 2013. Belajar dan Pembelajaran Sains. Bandung: Rineka Cipta.

[11] Lisniandila, N. P., Santyasa, I. W., \& Suswand, I. (2019). The effect of problem based learning teaching method on students' critical thinking skills in physics lesson at SMA Negeri 4 Singaraja. JPP (Jurnal Pendidikan Dan Pembelajaran), 25(1), 16-24. https://doi.org/10.17977/um047v25i12018p016

[12] Liyuan, G., \& Group, F. (2017). Does problem based learning improve critical thinking skill? Cakrawala Pendidikan, 3(October), 1-29.

[13] Masek, Alias dan Yamin, Sulaiman. 2011. The effect of problem based learning on critical thinking ability: a theoretical and empirical review. International Review of Social Sciences and Humanities. ISSN 2248-9010 (online), ISSN 2250-0715 (print), Vol.2, No.1, (hal 217).

[14] M, Hamdani., B.A, Prayitno., \& P, Karyanto. (2012). Meningkatkan kemampuan berpikir 
kritis melalui metode eksperimen the improveability to think critically through the experimental method. Proceeding Biology Education ..., 16(Kartimi), 139-145. https://jurnal.uns.ac.id/prosbi/article/view/38412

[15] Permata, A. R., Muslim, M., \& Suyana, I. (2019). Analisis kemampuan berpikir kritis siswa SMA pada materi momentum dan impuls. Seminar Nasional Fisika, 8, 9-16. https://doi.org/10.21009/03.snf2019.01.pe.02

[16] Pratama, N. S., \& Istiyono, E. (2015). Studi pelaksanaan pembelajaran fisika berbasis higher order thinking (hots) pada kelas X di SMA Negeri Kota Yogyakarta. Seminar Nasional Fisika Dan Pendidikan Fisika, 6(2), 104-112. http://jurnal.fkip.uns.ac.id/index.php/prosfis1/article/view/7711/5687

[17] Priyadi, R., Mustajab, A., Tatsar, M. Z., \& Kusairi, S. (2018). Analisis kemampuan berpikir kritis siswa SMA Kelas X MIPA dalam Pembelajaran Fisika. JPFT (Jurnal Pendidikan Fisika Tadulako Online), 6(1), 53. https://doi.org/10.22487/j25805924.2018.v6.i1.10020

[18] Pursitasari, I. D., Suhardi, E., Putra, A. P., \& Rachman, I. (2020). Enhancement of student's critical thinking skill through science context-based inquiry learning. Jurnal Pendidikan IPA Indonesia, 9(1), 97-105. https://doi.org/10.15294/jpii.v9i1.21884

[19] Purwati, R., Hobri, \& Fatahillah, A. (2007). Analisis kemampuan berpikir kritis pesera didik dalam menyelesaikan masalah persamaan kuadrat pada pembelajaran model creative problem solving. Journal of Food System Research, 14(2), 70-75. https://doi.org/10.5874/jfsr.14.2_70

[20] Rubiyanti, Badarudin, \& Eka, K. I. (2020). Improving critical thinking skills and learning independence using problem based learning based on science literation. Indonesian Journal of Educational Studies (IJES), 23(1), 34-43.

[21] Rusman. 2013. Model-Model Pembelajaran. Jakarta: Rajawali Pers.

[22] Sam, H. N., \& Qohar, A. (2016). Pembelajaran berbasis masalah berdasarkan langkah langkah polya untuk meningkatkan kemampuan menyelesaikan soal cerita matematika. Kreano, Jurnal Matematika Kreatif-Inovatif, 6(2), 156. https://doi.org/10.15294/kreano.v6i2.5188

[23] Siahaan, Y. L. O., \& Meilani, R. I. (2019). Sistem kompensasi dan kepuasan kerja guru tidak tetap di sebuah SMK swasta di Indonesia. Jurnal Pendidikan Manajemen Perkantoran, 4(2), 141. https://doi.org/10.17509/jpm.v4i2.18008

[24] Siregar, S. A., \& Ramadhani, D. (2019). Analisis kemampuan berpikir kritis pesera didik pada tema 8 " lingkungan sahabat kita" SD Negeri 6 Langsa. Journal of Basic Education Studies, 2(1), $112-123$.

[25] Sulaiman, A., \& Syakarofath, N. A. (2018). Berpikir kritis: Mendorong Introduksi dan reformulasi konsep dalam Psikologi Islam. Buletin Psikologi, 26(2), 86. https://doi.org/10.22146/buletinpsikologi.38660

[26] Suprapto, N., Suliyanah, \& Admoko, S. (2013). Pembelajaran fisika di SMA melalui pertanyaan (learning by questioning) dan keterampilan berpikir. Jurnal Penelitian Fisika Dan Aplikasinya (JPFA), 3(2), 1-11.

[27] Suriani, W. O., Rm, V. H., \& Sukariasih, L. (2019). Penerapan model pembelajaran berbasis masalah untuk meningkatkan keterampilan berpikir kritis dan hasil belajar pada materi pokok hukum newton peserta didik kelas X IPA2 SMA Negeri 1 Parigi. Jurnal Penelitian Pendidikan Fisika, 4(4), 196-201.

[28] Surya, Mohamad. 2015. Strategi Kognitif dalam Proses Pembelajaran. Bandung: Alfabeta.

[29] Susilowati, Sajidan, \& Ramli, M. (2017). Analisis keterampilan berpikir kritis siswa madrasah aliyah negeri di Kabupaten Magetan. Seminar Nasional Pendidikan Sains 2017 Dengan Tema "Strategi Pengembangan Pembelajaran Dan Penelitian Sains Untuk Mengasah Keterampilan Abad 21 (Creativity and Innovation, Critical Thinking and Problem Solving, Communication, Collaboration/4C)", 21(2000), 223-231. http://www.jurnal.fkip.uns.ac.id/index.php/snps/article/viewFile/11417/8102. 
[30] Sutisnawati, A. (2017). Analisis keterampilan dasar mengajar mahasiswa calon guru sekolah dasar. Mimbar Pendidikan Dasar, 8(1), 15-24. file:///C:/Users/user/Downloads/7886-15676-1-SM (2).pdf

[31] Utami, B., Saputro, S., Ashadi, A., Masykuri, M., \& Widoretno, S. (2017). Critical thinking skills profile of high school students in learning chemistry. International Journal of Science and Applied Science: Conference Series, 1(2), 124. https://doi.org/10.20961/ijsascs.v1i2.5134

[32] Yanti, F., Sukarmin, S., \& Suparmi, S. (2016). Pengembangan modul pembelajaran fisika SMA/MA berbasis masalah untuk meningkatkan keterampilan berpikir kritis siswa. Inkuiri, 4(3), 96-103. 